\title{
Increased Effect-Site Concentration of Propofol Reduces EC 50 of Remifentanil for Successful Intubation Using the Shikani Optical Stylet without Neuromuscular Blockade
}

\author{
Sang Yun Cho, Chang Wook Lee, Hyung Joon Park, Seong Ho Park, Woo Jae Jeon
}

Department of Anaesthesiology and Pain Medicine, Hanyang University Guri Hospital, Hanyang University College of Medicine, Guri, Korea

\begin{abstract}
Objective: For short-duration surgery, propofol and remifentanil are the drugs of choice for intubation without neuromuscular blockade. The Shikani Optical Stylet (SOS) is a novel semi-rigid type fiberoptic laryngoscope. In this study, we determined the clinically required effect-site concentration of remifentanil for intubation using SOS without neuromuscular blockade depending on propofol effect-site concentration.

Methods: We enrolled patients scheduled for elective surgery with general anesthesia, and assigned them into two groups by a randomized, double-blind method: concentration of propofol $3.5 \mu \mathrm{g} / \mathrm{mL}$ (group PRO 3.5) and $7.0 \mu \mathrm{g} / \mathrm{mL}$ (group PRO 7.0). Anesthesia was conducted with target-controlled infusion in predetermined target effect-site concentrations of propofol. The concentration of remifentanil for successful intubation using SOS in $50 \%$ of patients ( $\left.\mathrm{EC}_{50}\right)$ was determined using a modified Dixon's up-anddown method.

Results: The mean \pm standard deviation $\mathrm{EC}_{50}$ of remifentanil was $5.07 \pm 0.40 \mathrm{ng} / \mathrm{mL}$ in group PRO 3.5 and $1.79 \pm 0.44 \mathrm{ng} / \mathrm{mL}$ in group PRO 7.0. From probit analysis, $\mathrm{EC}_{50}$ and $\mathrm{EC}_{95}$ of remifentanil in group PRO 3.5 were $4.85 \mathrm{ng} / \mathrm{mL}$ (95\% confidence interval [Cl], 4.44 $5.16 \mathrm{ng} / \mathrm{mL})$ and $5.42 \mathrm{ng} / \mathrm{mL}(95 \% \mathrm{Cl}, 5.13-7.47 \mathrm{ng} / \mathrm{mL})$ respectively, and $\mathrm{EC}_{50}$ and $\mathrm{EC}_{95}$ of remifentanil in group PRO 7.0 were 1.68 $\mathrm{ng} / \mathrm{mL}(95 \% \mathrm{Cl}, 1.22-2.01 \mathrm{ng} / \mathrm{mL}$ ) and $2.29 \mathrm{ng} / \mathrm{mL}(95 \% \mathrm{Cl}, 1.98-4.05 \mathrm{ng} / \mathrm{mL})$, respectively.

Conclusion: Increased concentration of propofol reduced $\mathrm{EC}_{50}$ of remifentanil for successful intubation using SOS without neuromuscular blockade.
\end{abstract}

Keywords: Propofol; Remifentanil; Intubation

\section{INTRODUCTION}

Even though propofol can relax the jaw and suppress airway reflexes, which makes it one of the most useful induction drugs for intubation without neuromuscular blockade, adjuvants may be needed in many cases [1,2]. Opioids are suitable for this purpose, and among them remifentanil is an ultrashort-acting potent opioid metabolized by non-specific plasma and tissue esterase. Currently combinations of propofol and remifentanil using targetcontrolled infusion (TCI) device are more frequently used.

The Shikani Optical Stylet (SOS; Clarus Medical, Minneapolis, MN, USA), a device for difficult intubation which was approved by the Food and Drug Administration in 1996, is unfamiliar to many anesthesiologists, consequently, not only a few studies about it are available but also none of them related to intubation using propofol and remifentanil [3].

The aims of this study were to determine the clinically required effect-site concentration (Ce) of remifentanil for intubation using SOS without neuromuscular blockade and to examine to what extent propofol reduces $\mathrm{Ce}$ of remifentanil and improves conditions for intubation.

\section{MATERIALS AND METHODS}

Once institutional review board approval from Hanyang University Guri Hospital was obtained (IRB approval no., 2010-70), we 
gathered 47 patients who were going to have surgery with general anesthesia and received from them written informed consent and authorization to enroll them in our study. Patients were suitable for intubation with SOS. Members of our study were between 18 and 65 years old, American Society of Anesthesiologists status I or II. Patients expected to be difficult for intubation, respiratory tract infection history, cardiovascular disease, taking pain control medications, or body mass index $(\mathrm{BMI})>30 \mathrm{~kg} / \mathrm{m}^{2}$ were eliminated from the study.

The patients were assigned into two groups by a randomized, double-blind method: Ce of propofol $3.5 \mu \mathrm{g} / \mathrm{mL}$ with remifentanil (group PRO 3.5) and Ce of propofol $7.0 \mu \mathrm{g} / \mathrm{mL}$ with remifentanil (group PRO 7.0). All patients were previously medicated with atropine $0.5 \mathrm{mg}$ and midazolam $0.05 \mathrm{mg} / \mathrm{kg}$ intramuscular injection before surgery. In the operation room, we recorded age, sex, weight, height, BMI, Mallampati class, thyromental distance, maximal mouth opening (inter-incisor distance), and standard monitoring was documented (electrocardiogram, pulse oximeter, blood pressure, and end-tidal $\mathrm{CO}_{2} \mathrm{Ce}$ ). Anesthetic depth was checked with the bispectral index (BIS) monitor (A-2000, ver. 3.3; Aspect Medical System Inc., Natick, MA, USA).

All subjects of our study were previously oxygenated with $100 \%$ oxygen for 3 minutes. To decrease propofol-induced injection pain, $40 \mathrm{mg}$ intravenous lidocaine was injected, and induction was done with Ce of propofol 3.5 or $7.0 \mu \mathrm{g} / \mathrm{mL}$ using a TCI device (Orchestra; Fresenius Vial, Brezins, France). We applied the Schnider pharmacokinetic model for propofol $[4,5]$. Immediately after starting propofol using TCI, remifentanil was infused using TCI at a predetermined Ce. We applied the Minto pharmacokinetic model for remifentanil [6].

After loss of consciousness, mask ventilation was maintained with $100 \%$ oxygen. Propofol and remifentanil infusion was done for 4 more minutes after which endotracheal intubation was done by the same anesthesiologist for all the patients. For intubating men, we used endotracheal tube internal diameter $7.5 \mathrm{~mm}$ and for women, $6.5 \mathrm{~mm}$. The total intubation time was defined as the time elapsed between inserting the SOS into the oral cavity and the verification of tracheal intubation with the visualization of three end tidal $\mathrm{CO}_{2}$ waveforms, during mechanical ventilation with a tidal volume of $10 \mathrm{~mL} / \mathrm{kg}$ at a respiratory rate of 20 breaths/min. After intubation, BIS index was recorded and the total amount of propofol and remifentanil used till intubation was recorded. Intubating conditions were evaluated according to a scoring system described by Viby-
Table 1. Assessment of intubating conditions

\begin{tabular}{llll}
\hline \multirow{2}{*}{ Variable } & \multicolumn{3}{c}{ Intubating conditions } \\
\cline { 2 - 4 } & Acceptable & \multicolumn{1}{c}{ Unacceptable } \\
\cline { 2 - 4 } & Excellent & \multicolumn{1}{c}{ Good } & \multicolumn{1}{c}{ Poor } \\
\hline $\begin{array}{l}\text { Ease of laryngoscopy } \\
\text { (jaw relaxation) }\end{array}$ & Easy & Fair & Difficult \\
Vocal cord position & Abducted & Intermediate & Closed \\
Vocal cord movement & None & Moving & Closing \\
Airway reaction (coughing) & None & Diaphragm & Sustained (>10 sec) \\
Movement of the limbs & None & Slight & Vigorous \\
\hline
\end{tabular}

Excellent: all criteria are excellent; good: all criteria are excellent or good; poor: the presence of a single criterion listed under 'poor.'

Mogensen (Table 1) [7]. After successful or failed intubation, all data was recorded, and Ce of propofol and remifentanil was not disclosed to the intubating anesthesiologist; thus, a double-blinded method was achieved.

Successful intubation was defined as 'excellent' or 'good' intubating conditions. If intubation failed due to movement, inadequate jaw relaxation, cough, or closed vocal cords, rocuronium 0.6 $\mathrm{mg} / \mathrm{kg}$ was administered and intubation was performed following neuromuscular blockade. The Ce of remifentanil for successful intubation using SOS in 50\% of patients $\left(\mathrm{EC}_{50}\right)$ was established using the modified Dixon's up-and-down method [8,9]. As a pilot study, we enrolled 12 patients to determine the initial Ce of remifentanil for this study. The first patients received a Ce of remifentanil of $5 \mathrm{ng} / \mathrm{mL}$ in group PRO 3.5 and $3 \mathrm{ng} / \mathrm{mL}$ in group PRO 7.0.

If the response of patient was good or excellent, the next Ce of remifentanil was decreased by a step of $1.0 \mathrm{ng} / \mathrm{mL}$. If patient response was 'poor,' the Ce was increased by $1.0 \mathrm{ng} / \mathrm{mL}$. The stepchange of Ce was decreased to $0.5 \mathrm{ng} / \mathrm{mL}$, following the initial three 'negative-positive up-and-down' cross-overs. Same method was done again until seven cross-over midpoints (poor/excellent or good) were acquired. Tracheal intubation in 50\% of patients $\left(\mathrm{EC}_{50}\right)$ of remifentanil was determined by calculating the mean of the midpoint $\mathrm{Ce}$ of all independent pairs of patients who manifested a cross-over from a negative to a positive response [8]. In the post anesthetic care unit patients were asked if they had any memory recall.

SPSS ver. 17.0 for Windows (SPSS Inc., Chicago, IL, USA) and SigmaStat ver. 3.5 (Systat Software Inc., San Jose, CA, USA) was used to do statistical analysis. Probit analysis in PASW ver. 18.0 (SPSS Inc.) was used to establish $\mathrm{EC}_{50}$ and $\mathrm{EC}_{95}$ with 95\% confidence intervals (CI). Age, weight, height, BMI, thyromental dis- 
tance, maximal mouth opening (inter-incisor distance), total intubation time, BIS after intubation, and total dose of propofol and remifentanil were analyzed with t-test. Sex, Mallampati class, and intubating condition of successful intubation patients were analyzed with Fisher's exact test. Values are denominated as mean \pm standard deviation or number of patients and $\mathrm{P}<0.05$ was considered significant.

Table 2. Characteristics and airway classification of successful intubated patients

\begin{tabular}{lcc}
\hline Characteristic & Group PRO $3.5(\mathrm{n}=13)$ & Group PRO $7.0(\mathrm{n}=12)$ \\
\hline Age $(\mathrm{yr})$ & $37.0(15.0)$ & $31.3(11.0)$ \\
Sex $(\mathrm{female} / \mathrm{male})$ & $8 / 5$ & $8 / 4$ \\
Weight $(\mathrm{kg})$ & $59.7 \pm 9.2$ & $55.9 \pm 8.8$ \\
Height $(\mathrm{cm})$ & $163.7 \pm 7.1$ & $163.9 \pm 9.5$ \\
Body mass index $\left(\mathrm{kg} / \mathrm{m}^{2}\right)$ & $22.2 \pm 2.5$ & $20.7 \pm 2.2$ \\
Mallampati class $(\mathrm{l} / \mathrm{II})$ & $9 / 4$ & $8 / 4$ \\
Thyromental distance $(\mathrm{mm})$ & $74.2 \pm 10.3$ & $76.0 \pm 7.6$ \\
Maximal mouth opening $(\mathrm{mm})$ & $43.2 \pm 6.3$ & $45.5 \pm 6.4$ \\
\hline
\end{tabular}

Values are presented as number of patients $(\%)$ or mean \pm standard deviation. Group PRO 3.5: effect-site concentration of propofol $3.5 \mu \mathrm{g} / \mathrm{mL}$ with remifentanil; group PRO 7.0: effect-site concentration of propofol $7.0 \mu \mathrm{g} / \mathrm{mL}$ with remifentanil. There were no significant differences between the groups.

Table 3. Response to successful intubation

\begin{tabular}{|c|c|c|}
\hline Variable & Group PRO 3.5 & Group PRO 7.0 \\
\hline Successful intubation (success/total) & $13 / 25$ & $12 / 22$ \\
\hline \multicolumn{3}{|l|}{ Jaw relaxation } \\
\hline Easy & 10 & 10 \\
\hline Fair & 3 & 2 \\
\hline \multicolumn{3}{|l|}{ Vocal cord position } \\
\hline Abducted & 12 & 12 \\
\hline Intermediate & 1 & 0 \\
\hline \multicolumn{3}{|l|}{ Vocal cord movement } \\
\hline None & 11 & 12 \\
\hline Moving & 2 & 0 \\
\hline \multicolumn{3}{|l|}{ Airway reaction (coughing) } \\
\hline None & 2 & 2 \\
\hline Diaphragm (1-2) & 11 & 10 \\
\hline \multicolumn{3}{|l|}{ Movement of limbs } \\
\hline None & 3 & 2 \\
\hline Slight & 10 & 10 \\
\hline Total intubation time (sec) & $39.2 \pm 19.3$ & $38.0 \pm 20.4$ \\
\hline Bispectral index after intubation & $56.2 \pm 14.0$ & $30.1 \pm 10.2^{*}$ \\
\hline Propofol dose before intubation (mg) & $93.6 \pm 7.7$ & $187.5 \pm 12.7^{*}$ \\
\hline Remifentanil dose before intubation $(\mu \mathrm{g})$ & $138.6 \pm 20.3$ & $53.1 \pm 14.4^{*}$ \\
\hline
\end{tabular}

Values are presented as number of patients $(\%)$ or mean \pm standard deviation. Group PRO 3.5: effect-site concentration of propofol $3.5 \mu \mathrm{g} / \mathrm{mL}$ with remifentanil; group PRO 7.0: effect-site concentration of propofol $7.0 \mu \mathrm{g} / \mathrm{mL}$ with remifentanil.

${ }^{*} \mathrm{P}<0.05$ compared with group PRO 3.5 .

\section{RESULTS}

There were no significant differences between the two groups in age, sex, weight, height, BMI, Mallampati class, thyromental distance, and maximal mouth opening (inter-incisor distance) (Table 2).

There were no cases of airway trauma, memory recall, or significant hypotension or bradycardia. In group PRO 3.5, 25 patients were enrolled of which 13 were successfully intubated, and in group PRO 7.0, 22 patients were enrolled into this study in which 12 were successfully intubated. There were no significant differences in response to successful intubation in group PRO 3.5 and group PRO 7.0, but BIS after intubation were significantly elevated in group PRO $3.5(\mathrm{P}<0.001)$ (Table 3$)$.

Figs. 1 and 2 show individual Ce-responses according to the upand-down sequence in group PRO 3.5 and group PRO 7.0. From the modified Dixon's up-and-down method, $\mathrm{EC}_{50}$ of remifentanil for intubation using SOS was $5.07 \pm 0.40 \mathrm{ng} / \mathrm{mL}$ in group PRO 3.5 and $1.79 \pm 0.44$ in group PRO 7.0.

From probit analysis, $\mathrm{EC}_{50}$ and $\mathrm{EC}_{95}$ were $4.85 \mathrm{ng} / \mathrm{mL}$ (95\% CI, 4.44-5.16 ng/mL) and 5.42 ng/mL (95\% CI, 5.13-7.47 ng/mL) in group PRO 3.5, respectively, and $\mathrm{EC}_{50}$ and $\mathrm{EC}_{95}$ were $1.68 \mathrm{ng} / \mathrm{mL}$ (95\% CI, 1.22-2.01 ng/mL) and $2.29 \mathrm{ng} / \mathrm{mL}$ (95\% CI, 1.98-4.05 ng/ $\mathrm{mL}$ ) in group PRO 7.0, respectively. Dose-response curves for each patient obtained by the up-and-down method are shown in Fig. 3.

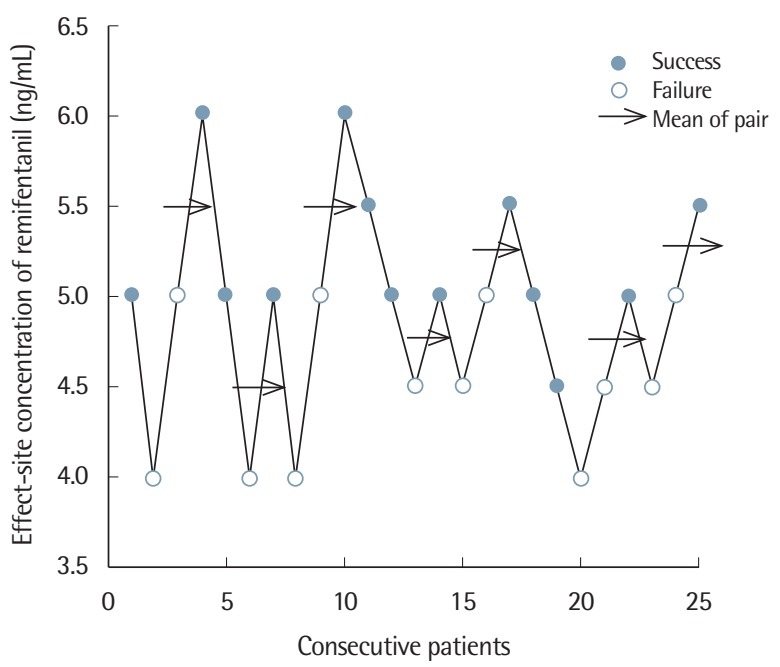

Fig. 1. Patient's intubating condition for intubation using Shikani Optical Stylet during effect-site concentration of propofol $3.5 \mu \mathrm{g} / \mathrm{mL}$. Arrows indicate the midpoint of the effect-site concentration of all independent pairs of patients involving cross-over from a negative response to a positive response (i.e., from failure to success of intubation). Effect-site concentration of remifentanil for successful intubation in $50 \%$ of patients was $5.07 \pm 0.40 \mathrm{ng} / \mathrm{mL}$. 


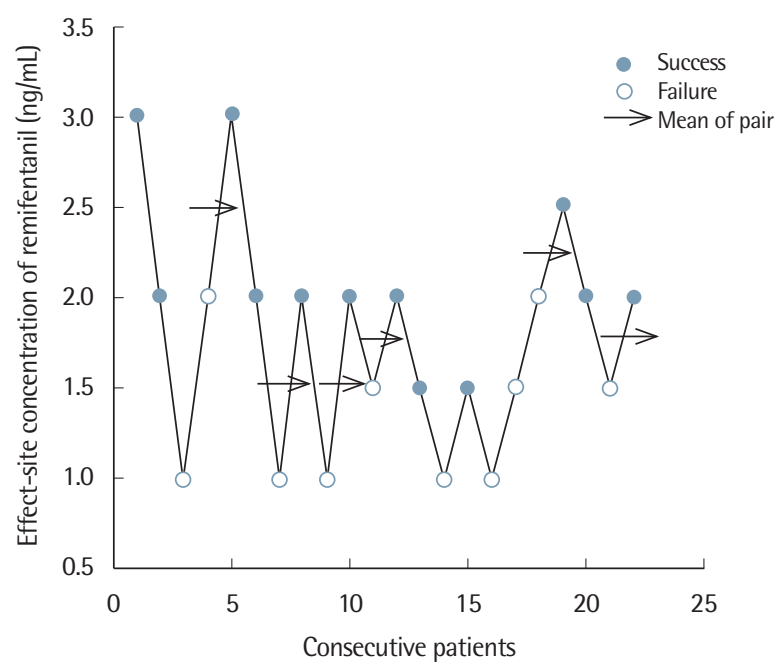

Fig. 2. Patient's intubating condition for intubation using Shikani Optical Stylet during effect-site concentration of propofol $7 \mu \mathrm{g} / \mathrm{mL}$. Arrows indicate the midpoint of the effect-site concentration of all independent pairs of patients involving cross-over from a negative response to a positive response (i.e., from failure to success of intubation). Effect-site concentration of remifentanil for successful intubation in $50 \%$ of patients was $1.79 \pm 0.44 \mathrm{ng} / \mathrm{mL}$.

\section{DISCUSSION}

Using the modified Dixon's up-and-down method, this study demonstrated that the required Ce of remifentanil at which successful intubation is possible in $50 \%$ of patients was $5.07 \pm 0.40 \mathrm{ng} / \mathrm{mL}$ during a TCI of propofol $3.5 \mu \mathrm{g} / \mathrm{mL}$, and $1.79 \pm 0.44 \mathrm{ng} / \mathrm{mL}$ during a TCI of propofol $7.0 \mu \mathrm{g} / \mathrm{mL}$.

During induction of anesthesia using propofol, combined use of opioids is needed to suppress hemodynamic instability [10]. Recently among opioids, remifentanil is used as an adjuvant more frequently because it has a fast onset time and no accumulation effect due to continuous infusion. Also, its context-sensitive half-life is shorter; therefore, emergence is faster [11].

In this study, we used TCI for continuous infusion because it results in fewer overdose-linked adverse effects and provides greater cardiovascular stability compared with traditional weigh-adjusted infusions. Also, TCI targets the Ce rather than the plasma Ce because it more accurately reproduces the desired time course of drug effect $[4,12]$.

There are many studies related to propofol-remifentanil TCI induction methods to suppress hemodynamic instability [13-15]. Albertin et al. [13] suggested that $\mathrm{EC}_{50}$ of remifentanil during intubation is $5.0 \mathrm{ng} / \mathrm{mL}$ (95\% CI, 4.7-5.4 ng/mL) while using Ce of propofol $4 \mu \mathrm{g} / \mathrm{mL}$, which is similar to the results of our study in group

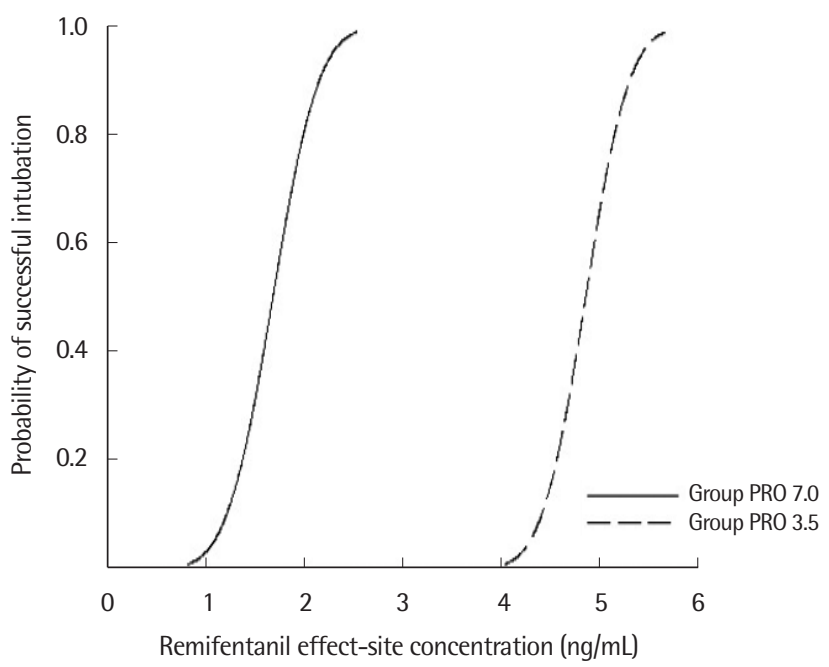

Fig. 3. Dose-response curves from probit analysis of individual effect-site concentration of remifentanil and reaction to intubation in the patients. Effect-site concentration of remifentanil during propofol $7.0 \mu \mathrm{g} / \mathrm{mL}$ at which there was a $50 \%$ and $95 \%$ probability of successful intubation was $1.68 \mathrm{ng} / \mathrm{mL}$ and $2.29 \mathrm{ng} /$ $\mathrm{mL}$, respectively (group PRO 7.0). Also the effect-site concentration of remifentanil during propofol $3.5 \mu \mathrm{g} / \mathrm{mL}$ at which there was a $50 \%$ and $95 \%$ probability of successful intubation was $4.85 \mathrm{ng} / \mathrm{mL}$ and $5.42 \mathrm{ng} / \mathrm{mL}$, respectively (group PRO 3.5).

PRO 3.5. Mustola and Toivonen [14] suggested that $\mathrm{EC}_{50}$ and $\mathrm{EC}_{95}$ of remifentanil is $3.17 \mathrm{ng} / \mathrm{mL}$ and $3.79 \mathrm{ng} / \mathrm{mL}$, respectively, during intubation while using Ce of propofol $4 \mu \mathrm{g} / \mathrm{mL}$, and this study showed lower Ce compared with our group PRO 3.5. Troy et al. [15] consider that a Ce of remifentanil $8 \mathrm{ng} / \mathrm{mL}$ along with a Ce of propofol $3 \mu \mathrm{g} / \mathrm{mL}$ may provide satisfactory conditions for intubation while avoiding major adverse effect, compared with our study in group PRO 3.5 in which $\mathrm{EC}_{95}$ was $5.42 \mathrm{ng} / \mathrm{mL}$ (95\% CI, 5.13$7.47 \mathrm{ng} / \mathrm{mL}$ ), showing a higher Ce.

In a pilot study, we enrolled 12 patients to determine the initial Ce of remifentanil for successful intubation, in which hypotension or bradycardia was minimal. Initial Ce of remifentanil for group PRO 3.5 and group PRO 7.0 was $5 \mathrm{ng} / \mathrm{mL}$ and $3 \mathrm{ng} / \mathrm{mL}$, respectively.

Recently, many devices are used for intubation. Aside from the traditional Macintosh laryngoscope, the GlideScope is one of the latest devices for intubation. Ithnin et al. [16] suggested that when Ce of propofol $3 \mu \mathrm{g} / \mathrm{mL}$ was used for intubation using a Macintosh laryngoscope, $\mathrm{EC}_{50}$ of remifentanil was $4.41 \mathrm{ng} / \mathrm{mL}$, and using the GlideScope, $\mathrm{EC}_{50}$ of remifentanil was $5.45 \mathrm{ng} / \mathrm{mL}$, showing that $\mathrm{EC}_{50}$ of remifentanil was higher in the latter one. Comparing this with our study $\left(\mathrm{EC}_{50}\right.$ of remifentanil $5.07 \mathrm{ng} / \mathrm{mL}$ in group PRO 3.5), $\mathrm{EC}_{50}$ using the Macintosh laryngoscope was lower and using 
the GlideScope, it was higher. The lightwand is the most similar to SOS, and Masso et al. [17] made a study using continuous infusion of propofol and remifentanil using a lightwand for intubation, but we could not compare our study with it because they did not use TCI.

Even though it is not intubation, Kim et al. [18] used Ce of propofol $3.5 \mu \mathrm{g} / \mathrm{mL}$ for laryngeal mask airway (LMA) insertion requiring $\mathrm{EC}_{50}$ of remifentanil $3.04 \pm 0.49 \mathrm{ng} / \mathrm{mL}$. Comparing it with our study, LMA insertion requires lower $\mathrm{EC}_{50}$ of remifentanil than intubation using the SOS because the former one is less painful. And Jeon et al. [19] suggested that optimal Ce of remifentanil using Ce of $6 \mu \mathrm{g} / \mathrm{mL}$ propofol for Cobra perilarygeal airway insertion is $4 \mathrm{ng} / \mathrm{mL}$. Although Ce of propofol is different from our study, comparing it with group PRO 7.0 the Ce was higher.

SOS is a novel fiberoptic endoscopy. It consists of a malleable stainless steel fiberoptic stylet and an eyepiece which can either be connected to a video camera and monitor or used on its own with the light source. This device has both features of fiberoptic bronchoscope and lightwand. The endotracheal tube is inserted in the stylet and like using a lightwand, the oropharynx is opened and looking through the bronchoscope vocal cord and trachea can be confirmed [3,20]. The device is lightweight, portable, sturdy, and can be used by a single operator. Yao et al. [21], after comparing intubation using SOS versus Macintosh laryngoscope, suggested that SOS airway trauma is less and intubation time is faster; also, hemodynamics are more stable.

Kil et al. [22] suggested that optimal Ce to maintain adequate BIS and hemodynamic stability with propofol for Koreans was 3.5 $\mu \mathrm{g} / \mathrm{mL}$, thus in this study using SOS for intubation, we used a Ce of $3.5 \mu \mathrm{g} / \mathrm{mL}$ and $7.0 \mu \mathrm{g} / \mathrm{mL}$ to find the optimal Ce of remifentanil. In this study, BIS after intubation in group PRO 3.5 was higher than in group PRO 7.0, 56.2 \pm 14.0 , and 30.1 \pm 10.2 , respectively. Especially, six patients among 25 showed BIS higher than 65 in group PRO 3.5 compared to none among 22 patients in group $\mathrm{PRO} 7.0(\mathrm{P}=$ 0.023). In this study, none of the patients had memory recalls, but it should be noticed that there can be memory recalls if Ce of propofol $3.5 \mu \mathrm{g} / \mathrm{mL}$.

Park et al. [23] suggested that during insertion of LMA and laryngeal tube, Ce of propofol can be decreased by half when Ce of remifentanil is doubled. In our study $\mathrm{EC}_{50}$, of remifentanil in group PRO 3.5 was $5.07 \pm 0.40 \mu \mathrm{g} / \mathrm{mL}$ and $\mathrm{EC}_{50}$ of remifentanil in group PRO 7.0 was $1.79 \pm 0.44 \mu \mathrm{g} / \mathrm{mL}$, showing that doubling the Ce of propofol allowed us to reduce the Ce of remifentanil by more than half. We recommend a Ce of $7.0 \mu \mathrm{g} / \mathrm{mL}$ rather than $3.5 \mu \mathrm{g} / \mathrm{mL}$ propofol because Ce of remifentanil can be lowered and no elevations of BIS are shown after intubation using SOS.

In conclusion, the $\mathrm{Ce}$ of remifentanil for successful intubation using SOS without neuromuscular blockade in $50 \%$ of patients $\left(\mathrm{EC}_{50}\right)$ in group PRO 3.5 was $5.07 \pm 0.40 \mathrm{ng} / \mathrm{mL}$ and in group PRO 7.0 was $1.79 \pm 0.44 \mathrm{ng} / \mathrm{mL}$. From probit analysis, the $\mathrm{EC}_{50}$ and $\mathrm{EC}_{95}$ in group PRO 3.5 were $4.85 \mathrm{ng} / \mathrm{mL}$ (95\% CI, 4.44-5.16 ng/mL) and $5.42 \mathrm{ng} / \mathrm{mL}$ (95\% CI, 5.13-7.47 ng/mL), respectively, and the $\mathrm{EC}_{50}$ and $\mathrm{EC}_{95}$ in group PRO 7.0 were $1.68 \mathrm{ng} / \mathrm{mL}$ (95\% CI, 1.22-2.01 $\mathrm{ng} / \mathrm{mL}$ ) and $2.29 \mathrm{ng} / \mathrm{mL}$ (95\% CI, 1.98-4.05 ng/mL), respectively. Increased Ce of propofol reduced the $\mathrm{EC}_{50}$ of remifentanil for successful intubation using SOS without neuromuscular blockade.

\section{REFERENCES}

1. Taha S, Siddik-Sayyid S, Alameddine M, Wakim C, Dahabra C, Moussa A, et al. Propofol is superior to thiopental for intubation without muscle relaxants. Can J Anaesth 2005;52:249-53.

2. Batra YK, Al Qattan AR, Ali SS, Qureshi MI, Kuriakose D, Migahed A. Assessment of tracheal intubating conditions in children using remifentanil and propofol without muscle relaxant. Paediatr Anaesth 2004;14: 452-6.

3. Shikani AH. New "seeing" stylet-scope and method for the management of the difficult airway. Otolaryngol Head Neck Surg 1999;120:113-6.

4. Schnider TW, Minto CF, Gambus PL, Andresen C, Goodale DB, Shafer SL, et al. The influence of method of administration and covariates on the pharmacokinetics of propofol in adult volunteers. Anesthesiology 1998;88:1170-82.

5. Schnider TW, Minto CF, Shafer SL, Gambus PL, Andresen C, Goodale $\mathrm{DB}$, et al. The influence of age on propofol pharmacodynamics. Anesthesiology 1999;90:1502-16.

6. Minto CF, Schnider TW, Egan TD, Youngs E, Lemmens HJ, Gambus PL, et al. Influence of age and gender on the pharmacokinetics and pharmacodynamics of remifentanil: I. model development. Anesthesiology 1997; 86:10-23.

7. Viby-Mogensen J, Engbaek J, Eriksson LI, Gramstad L, Jensen E, Jensen FS, et al. Good clinical research practice (GCRP) in pharmacodynamic studies of neuromuscular blocking agents. Acta Anaesthesiol Scand 1996; 40:59-74.

8. Dixon WJ. Staircase bioassay: the up-and-down method. Neurosci Biobehav Rev 1991;15:47-50.

9. Choi SC. Interval estimation of the LD50 based on an up-and-down experiment. Biometrics 1990;46:485-92.

10. Kazama T, Ikeda K, Morita K. Reduction by fentanyl of the Cp50 values of propofol and hemodynamic responses to various noxious stimuli. Anesthesiology 1997;87:213-27.

11. Mertens MJ, Engbers FH, Burm AG, Vuyk J. Predictive performance of computer-controlled infusion of remifentanil during propofol/remifentanil anaesthesia. Br J Anaesth 2003;90:132-41.

12. Shafer SL, Gregg KM. Algorithms to rapidly achieve and maintain stable drug concentrations at the site of drug effect with a computer-controlled infusion pump. J Pharmacokinet Biopharm 1992;20:147-69. 
13. Albertin A, Casati A, Federica L, Roberto V, Travaglini V, Bergonzi P, et al. The effect-site concentration of remifentanil blunting cardiovascular responses to tracheal intubation and skin incision during bispectral index-guided propofol anesthesia. Anesth Analg 2005;101:125-30.

14. Mustola S, Toivonen J. Effect-site concentration of remifentanil attenuating surgical stress index responses to intubation of the trachea. Anaesthesia 2010;65:581-5.

15. Troy AM, Huthinson RC, Easy WR, Kenney GN. Tracheal intubating conditions using propofol and remifentanil target-controlled infusions. Anaesthesia 2002;57:1204-7.

16. Ithnin F, Lim Y, Shah M, Shen L, Sia AT. Tracheal intubating conditions using propofol and remifentanil target-controlled infusion: a comparison of remifentanil EC50 for Glidescope and Macintosh. Eur J Anaesthesiol 2009;26:223-8.

17. Masso E, Sabate S, Hinojosa M, Vila P, Canet J, Langeron O. Lightwand tracheal intubation with and without muscle relaxation. Anesthesiology 2006;104:249-54.

18. Kim MK, Lee JW, Jang DJ, Shin OY, Nam SB. Effect-site concentration of remifentanil for laryngeal mask airway insertion during target-controlled infusion of propofol. Anaesthesia 2009;64:136-40.

19. Jeon WJ, Kim KH, Suh JK, Cho SY. The use of remifentanil to facilitate the insertion of the Cobra perilaryngeal airway. Anesth Analg 2009;108: 1505-9.

20. Turkstra TP, Pelz DM, Shaikh AA, Craen RA. Cervical spine motion: a fluoroscopic comparison of Shikani Optical Stylet vs Macintosh laryngoscope. Can J Anaesth 2007;54:441-7.

21. Yao YT, Jia NG, Li CH, Zhang YJ, Yin YQ. Comparison of endotracheal intubation with the Shikani Optical Stylet using the left molar approach and direct laryngoscopy. Chin Med J (Engl) 2008;121:1324-7.

22. Kil HY, Lee SI, Lee SJ, Lee SW, Lee DH. The bispectral index and modified observer's assessment of alertness/sedation scale comparable to effect site concentration of propofol in Koreans. Korean J Anesthesiol 2000;38: 251-7.

23. Park HJ, Lee JR, Kim CS, Kim SD, Kim HS. Remifentanil halves the EC50 of propofol for successful insertion of the laryngeal mask airway and laryngeal tube in pediatric patients. Anesth Analg 2007;105:57-61. 